\title{
Model Design of Performance Improvement Strategy of Private Higher Education Using Analytic Hierarchy Process (AHP) Method and Mutivariate Data Analysis (MDA)
}

\author{
Sri Hartati ${ }^{1)}$, Kenny Puspita Sari' ${ }^{2)}$, Satria Abadi ${ }^{3 *}$ \\ 123) STMIK Pringsewu \\ Lampung, Indonesia \\ ${ }^{3)} \underline{\text { satria2601@gmail.com }}$
}

\begin{tabular}{l} 
Article history: \\
Received 01 December 2018; \\
Revised 4 December 2018; \\
Accepted 14 December 2018; \\
Available online 19 December 2018 \\
\hline
\end{tabular}

Keywords:

University Performance AHP

MDA

\begin{abstract}
The development of the number of Private Universities in Indonesia requires Private Universities to have good Performance and Quality. Private Universities must apply a new angle of thinking that contains elements of flexibility, speed, innovation, and integration. Flexibility, speed, innovation and integration really need human resources full of creativity. Creativity can arise from human resources who have excellence in science. Thus, Private Universities is expected to not only be able to produce the best graduates, but also be able to develop two things contained in the Tri Dharma of higher education, namely researching the results of high-quality research and developing technology for community service. For that Private Universities must always be able to adapt, develop and make improvements through organizational learning. This study aims to determine the strategy model for improving performance using a combination of AHP (Analytical Hierarchy Process) and Multivariate Data Analysis (MDA) methods. The sample of this research is management that manages Private Universities (Private Universities leaders) from several Private Universities in the Province of Lamping. AHP (Analytical Hierarchy Process) method is an analytical tool that can be used to make decisions on conditions with complex factors, especially if the decision is subjective. While the Multivariate Data Analysis (MDA) method refers to the statistical technique used to analyze data that appears from more than one variable. The results of this study indicate that there is a significant effect. Organizational Learning Factors, External Environment, Reputation, Competence, Professionalism, and Performance have a significant effect on Private Private Universities Performance. These criteria and sub-criteria are used as references for Private Universities management as a strategy to improve Private Universities performance in Lampung Province. This is basically a model of reality where each decision involves more than one single variable. This research is important to determine the best model in Private Universities Performance Improvement strategies. The results of this study contributed to the decision maker or management of Private Universities as a reference material in the member policies in improving the Performance of Private Universities.
\end{abstract}

\section{INTRODUCTION}

The development of the provision of Higher Education or Higher Education services in Indonesia is growing rapidly and is increasingly widespread. This can be seen from the development of the number of private institutions or institutions that are increasingly growing in various regions in Indonesia. One reason is the need for higher education services that are increasing from year to year causing the capacity of higher education services organized by the government to no longer be able to accommodate all prospective students. This gets a response from other community groups through offering educational services with a variety of attributes and interests. The regulations regarding the establishment of tertiary institutions are regulated in Government Regulation No. 57 of 1998 as a 
substitute for Government Regulation No. 30 of 1990. The main purpose of the establishment of Higher Education is as one of the national education instruments which is expected to be the center for the implementation and development of higher education as well as maintenance, development and development of science, technology and/or art as a scientific society that can improve the quality of life in society, nation and state. To achieve national education goals as stated in Law No. 20 of 2003 concerning the National Education System (SISDIKNAS).

Changes taking place in the global business environment have also triggered an increase in the intensity of competition among higher education service providers, so that each higher education service provider will try to offer high-performance higher education services. According to Kotler (2003), services are various actions or performance (performance) that can be offered by someone or an organization to other parties and are intangible and do not result in ownership of something.

Data obtained from the Directorate General of the Ministry of Research, Technology and Universities as of September 1, 2016 stated that the number of private universities in Indonesia showed a fairly rapid development. The number of Private Universities in Indonesia reaches 3940 PTS. The increase in the number of tertiary institutions in Indonesia has led to tighter competition, as shown in Figure 1.1. the following:

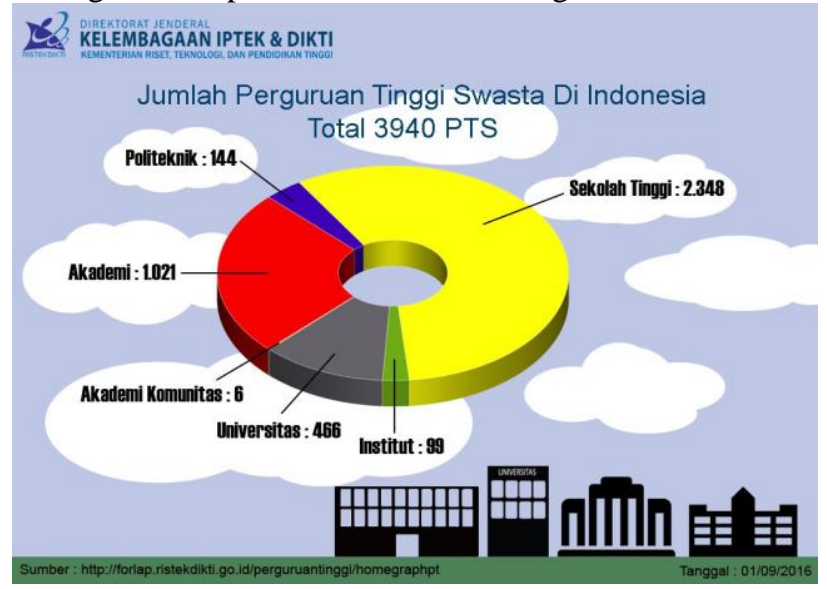

Fig 1. Number of Private Universities in Indonesia

When compared with the number of state universities with a total number of private universities in Indonesia, it can be seen that the number of private universities is very large compared to state universities which include Polytechnics, Academies, Colleges, Institutes and Universities. Following table 1.1 is the data on the number of comparisons each type of PT in Indonesia:

Table 1 Comparison of the Number of State and Private Universities in Indonesia

\begin{tabular}{lcc}
\hline \multirow{2}{*}{ Types of Universities } & \multicolumn{2}{c}{$\begin{array}{c}\text { Number of Higher } \\
\text { Education }\end{array}$} \\
\cline { 2 - 3 } & $\begin{array}{c}\text { Public } \\
\text { Universities }\end{array}$ & $\begin{array}{c}\text { Private } \\
\text { Universities }\end{array}$ \\
\hline Politeknik & 99 & 144 \\
Akademi & 86 & 1.021 \\
Sekolah Tinggi & 76 & 2.348 \\
Institute & 33 & 99 \\
Universitas & 75 & 466 \\
\hline \multicolumn{2}{c}{ Source: Statistik Dirjen Kemenristek tahun 2017 }
\end{tabular}

Table 1 shows that the difference in the number of private tertiary institutions $(2,348)$ and private universities (466) compared to the number of state high schools (76) and state universities (75) is very significant. However, this number is not followed by the performance of private universities that are comparable to the performance and quality of the state company. With the existence of a number of private universities which very much triggered intense competition. Each private higher education will improve higher education Performance and Quality as an indicator of the superiority of higher education.

Competition is described as a corporate cycle determined by four components of competition (4C), namely company, customers, competitors, and change (Kotler, 2003). For providers of private tertiary education, customers who immediately enjoy the services offered are students, competitors are providers of similar education services at 
the same level, and change includes all forms of change as internal initiatives and external pressures, both academic and non-academic. So that private higher education must improve the performance of the higher education in order to be able to excel in today's competitive competition.

The development of education in the last five years in Lampung Province is very rapid. Education delivery, especially the number of private universities is very significant compared to the previous five years. The total number of universities with private status in Lampung Province is 40 universities (PDPT Ministry of Research and Technology 2017) sources consisting of Universities, Institutes and Colleges. The efforts made by PTS in facing changes in the demands of society by carrying out organizational learning and the formation of reputations that influence the development of competency strategies, aim to improve their operational performance. According to Griffin (1987) performance describes how organizations become effective and shows the level of productivity of output, which is obtained through the management of organizational resources. The performance is shown through AIPT Accreditation Grade (Higher Education Institution Accreditation) in several recent universities issued by the Directorate General of Higher Education Ministry of Research and Technology Kopertis II region in 2017. The following are data on some of the Performance of Private Universities in Lampung Province that are up to date in 2017.

Table 2 Accreditation of several Private Universities in Lampung Province

\begin{tabular}{|r|l|l|l|l|}
\hline No & Nama Perguruan Tinggi & Daerah & Akreditasi & $\begin{array}{l}\text { Status } \\
\text { Kadaluarsa }\end{array}$ \\
\hline 1 & Akademi Akuntansi Lampung & Lampung & B & $29-01-2021$ \\
\hline 2 & Institut Informatika Dan Bisnis Darmajaya & Bandar Lampung & B & $05 / 09 / 2020$ \\
\hline 3 & Sekolah Tinggi Ilmu Ekonomi Gentiaras & Bandar Lampung & C & $30-08-2019$ \\
\hline 4 & Sekolah Tinggi Ilmu Ekonomi Lampung & Lampung Timur & C & $07 / 04 / 2020$ \\
\hline 5 & $\begin{array}{l}\text { Sekolah Tinggi Ilmu Hukum Muhammadiyah } \\
\text { Kotabumi }\end{array}$ & Lampung Utara & C & $22-06-2020$ \\
\hline 7 & Sekolah Tinggi Teknologi Nusantara & Bandar Lampung & C & $09 / 03 / 2020$ \\
\hline 8 & Universitas Sang Bumi Ruwa Jurai & Bandar Lampung & C & $10 / 03 / 2020$ \\
\hline
\end{tabular}

Sumber: Dirjen Kemenristek tahun 2017

Table 2 above shows that data in 2017, in some private universities in Lampung province the majority still have C accreditation, for Colleges, Institutes and even Universities. This phenomenon provides evidence that private universities must apply a new angle of thinking that contains elements of flexibility, speed, innovation and integration. According to Hidayat (2008) flexibility, speed, innovation and integration really need human resources full of creativity. Creativity can arise from human resources who have excellence in science. Thus, PTS is expected to not only be able to produce the best graduates, but also be able to develop two things contained in the Tri Dharma of higher education, namely researching the results of high-quality research and developing technology for community service. For that private universities are required to always be able to adapt, develop and make improvements through organizational learning (Henderson and Cockburn, 1994). As stated by Marquardt (1996) in order to achieve and maintain competitive advantage in a rapidly changing business environment, organizations must be able to increase their learning capacity.

The factors that surround the performance of higher education are very many. Several previous studies have examined several important factors that support improvement in organizational performance (Marquardt, 1996; Wang and Lo, 2003; Suta, 2005; Hidayat, 2008). The complexity of the supporting indicators in the Performance Improvement strategy requires a model of performance improvement strategies. This study aims to determine the strategy model for improving performance using a combination of AHP (Analytical Hierarchy Process) and Multivariate Data Analysis methods.

AHP (Analytical Hierarchy Process) method is a useful method to help decision makers to get the best decision by comparing the factors in the form of criteria (Feridani, 2005). AHP is an analytical tool that can be used to make decisions on conditions with complex factors, especially if the decision is subjective. With AHP, one can organize 
opinions and intuition by means of logic using hierarchies and incorporating judgments based on understanding and experience. This approach can accept uncertainty factors and allow changes so that individuals and groups can deal with all the simpler problems of comparison through hierarchies to arrive at all alternative priority actions (Saaty, 1993). While the Multivariate Data Analysis (MDA) method refers to the statistical technique used to analyze data that appears from more than one variable. This is basically a model of reality where each decision involves more than one single variable. (Hair, 1998) This research is important to determine the best model in PTS Performance Improvement strategies. The results of this study contribute to the decision maker or management of private universities as a reference material in member policies in improving the performance of higher education.

\section{Research Formulation}

Based on the description of the background above, the formulation of the problem of this research are:

1. Are the factors included in the criteria and determinants in the strategy to improve the performance of Private Universities in Lampung Province?

2. How are the weights and priorities of the criteria and the subcriteria for the assessment of determinants of higher education performance in Lampung Province using the AHP Method?

3. How is the relationship and influence of criteria and sub criteria on the performance of higher education using the Multivariate Data Analysis (MDA) method?

\section{Research purposes}

The objectives to be achieved in this study are:

1. Obtain factors that are included in the criteria and determinants in the strategy to improve the performance of Private Universities in Lampung Province

2. Determine the weight and priority of criteria and subcriteria for the assessment of higher education performance determinants in Lampung Province using the AHP Method

3. Analyzing the relationship and influence of criteria and sub criteria on the performance of higher education using the Multivariate Data Analysis (MDA) method.

\section{RELATED WORKS}

\section{Supporting Factors of Higher Education Performance}

\section{Organization}

Organizational learning in this study refers to the opinion of Garvin (2000) who defines organizational learning as the organization's expertise to create, obtain, interpret, transfer and share knowledge, which aims to modify the behavior of its members to develop new knowledge and insights. Because organizations learn through individuals in organizations, organizational learning in this study occurs through lecturer learning. Marquardt (1996) states that individual learning and organizational learning cannot be separated. Organizations learn through individuals who are part of the organization. Individual learning refers to changes in skills, insights, knowledge, attitudes, and values acquired by a person through experience, insight and observation.

2. External Environment

Environment is everything that is outside the organization (Khadekar and Sharma, 2006). Contingency theory also explains how strategic planning is able to meet the demands of the environment, which if it does not create harmony between strategic planning and the external business environment can result in decreased performance resulting in the emergence of organizational or corporate crises (Elenkov, 1997).

3. Reputation

According to the Resource-Based View of the Firm (RBV), reputation is included in the category of intangible assets (Michalisin, et al., 1997). As stated earlier, Barney (2002) also said that reputation is one of the key elements of intangible resources that will be the source of the creation of conditions for the excellence of a company's sustainable competitive advantage. Hall (1992, 1993) describes intangible resources as different feedstock capabilities (capability differential) that create sustainable competitive advantage and superior company performance.

4. Competence

Competence is the ability and knowledge of the company which is the basis for solving everyday problems (Henderson and Cockburn, 1994). Competence is based on information, tangible and intangible processes, and develops them over time through complex interactions between resources (Amit and Schoemaker, 1993). The strength of a company that cannot be easily matched or emulated by competitors is called competence (David, 2002). Competence is also expressed as the ability to organize work and convey values; competence 
can include communication, involvement and a large commitment to work along the boundary organizational boundaries (Prahalad and Hamel, 1990).

5. Professionalism

Professionalism competency is the ability to master learning material widely and deeply and the tridarma of higher education (Kusmanto, 2016). Kusmanto (2016) explains that professionalism includes (a) concepts, structures, and scientific / technological / art methods that overshadow / coherent with teaching material; (b) teaching materials that are in the madrasa curriculum; (c) the relationship of concepts between related subjects; (d) applying scientific concepts in daily life; and (e) professional competition in a global context while preserving national values and culture. In line

6. Performance

Mathis (2006), performance is basically an activity carried out or not carried out by an individual staff or employee. Performance generally consists of the following elements: (1) quantity of results, (2) quality of results, (3) timeliness of results, (4) attendance, and (5) ability to cooperate. Hasibuan (1997) says, the elements of performance include: employee responsibility, loyalty, discipline, quality and quantity of work, skills, communication skills and cooperation. According to Handoko (1985), several performance factors in the company include: personality, attitude, ambition, loyalty, interest in a job, responsibility, discipline, initiative, adjustment, cooperation, work knowledge, work productivity and leadership. According to Mangkuprawira (2002) that Performance is a multidimensional construction that includes many factors that influence it. These factors consist of intrinsic factors of employees (personal / individual) or HR and extrinsic, namely leadership, system, team, and situational.

\section{Decision Support System}

According to Mat and Watson (2000) Decision Support Systems (DSS) is an interactive system that helps decision making through the use of data and decision models to solve problems that are semi-structured and unstructured. Whereas according to Moore and Chang (1995) in Kusumadewi (2007), SPK is a system that can be developed, capable of supporting data analysis and decision modeling, oriented to future planning, and cannot be planned for the interval (period) of its use. Bonezek, Hosapple and Whinston (1995) in Kusumadewi (2007) defines SPK as a computer-based system consisting of 3 components that interact with each other.

1. Language system, is a mechanism for bridging (interface) users and other components.

2. Knowledge system, is a knowledge repository that deals with certain problems in the form of data and procedures.

3. Problem processing system, is a link between the two other components, containing one or several capabilities of manipulation or providing problems in general, which are needed in decision making.

\section{Analytic Hierarchy Process (AHP)}

In the early 1970s the Analytic Hierarchi Prosess (AHP) decision-making method was developed by one of the mathematics professors from the University of Fittsburgh, United States, this method was developed because to analyze the need for inadequate resource allocation and planning for military purposes.

AHP is an analytical tool that can be used to make decisions on conditions with complex factors, especially if the decision is subjectif (Bhutta and Haq, 2002). AHP produces a structured approach to determine the values and weights for multi-literacy problems and standardize them so that they can be compared with each other and a decision can be made.

\section{Basic Principles of AHP}

AHP is built based on fundamental facts and thoughts which are based on the basic human principles in analytical thinking as follows (Peniwati, 2000)

1. The human mind is able to compare two different objects related to their general nature.

2. Pairwise comparisons are the most accurate way to get relative priority from a set of objects.

3. Human thoughts are inconsistent, but individuals who have good information will have coherent thoughts (logically related). Being inconsistent is important for learning, but being consistent is more important for making decisions.

4. Quantitative data about problems must be converted into data that can be integrated with other qualitative information needed to consistently plan. Quantitative data in raw forms cannot be used for this purpose,

5. But is determined by natural measurements. For this reason, Saaty (1993) makes the AHP fundamental scale and maintains that objectivity is agreed to rather than subjectivity. Technically, the AHP application consists of 
compiling a hierarchy. get assessment through paired comparisons that will be synthesized into local and global priorities, ensure consistency at acceptable levels, evaluate outputs and make changes if needed.

\section{Preparation of Hierarchy}

Humans have the ability to perceive ideas, identify and communicate what is observed. To get detailed knowledge, pikrian humans compile complex reality into parts that become pokon elements yes and then arrange this part into its parts again, and so on in a hierarchical manner. (Saaty, 1993). The arrangement of this hierarchy is the most important stage in applying AHP as a model of the desired problem solved. In compiling this hierarchy creative thinking is needed, information gathering, information linking, remembering processes, parents' perspectives and also development. In practice, there are no standard procedures for forming goals, criteria and elements hidden in the hierarchy. The composition of the hierarchy is multilinear and composes from top to bottom the factors that are the most common and few can be controlled until the most common factors and few can be controlled until the factors are concrete and can be controlled (Peniwati, 2000)

\section{Determination of Priority}

Humans have the ability to prepare relationships between the things they observe, compare a pair of objects or things that are similar to certain criteria and distinguish between the two members of the pair by weighing the intensity of their preferences to each other. The intensity is called priority. (Saaty, 1993). The perceptions that decision makers or experts have with regard to priorities are obtained through a number of peer-to-peer comparisons that are made in the form of a matrix. The assessment matrix will be sentenced to be a local and global priority. This verbal assessment is connected on an absolute numerical scale.

\section{METHODS}

\section{Data Sources and Samples}

Data in this study were obtained from several private universities in Lampung Province. The research sample is respondents who have filled out questionnaires. Respondents of this study focused on PTS leaders (chancellor or assistant chancellor I, II, or III; directors or deputy directors I, II, or III; chairman or deputy chairman I, II, or III), where one PTS will be represented by one respondent. This study will describe the perceptions of PTS leaders regarding organizational learning, the influence of the external environment, reputation, competency strategy, and performance of the PTS. Selected PTS leaders as respondents, because they are considered to know the conditions in the PTS according to the variables of this study.

\section{Research Instrument}

In this study, researchers used questionnaires as research instruments, namely Phase 1 and 2. Questionnaires The selection criteria method and weighting sub criteria were divided into two stages of items, namely:

1. Selection criteria and sub-criteria (Phase I Questionnaire) which will be the main reference in the hierarchical model in determining Higher Education Performance using the Phase 1 questionnaire. Designing multiple attribute decision making systems with AHP. At this stage the researcher takes the criteria of the indicators made in determining the performance of the College and the gradation criteria will be made.

2. Phase II: Criteria for weighting and priority and subcriteria. 1. At this stage, based on the results of questionnaire 1, the questionnaire was developed for the second stage. In the phase 2 questionnaire, respondents were asked to determine the weighting criteria and sub criteria for filling out questionnaires in pairs by comparing the relative importance of criteria and subcriteria.

\section{Analysis Method}

Several stages are carried out in determining the supporting factors in the Higher Education performance improvement strategy that are shown using the flow chart in Figure 4.1. In particular, this study aims to qualitatively determine the important factors in improving university performance.

Stage 1: Identify the supporting factors for improving Higher Education Performance

Stage 3: Survey (Questionnaire I and II-using AHP Method)

Stage 4: Reliability Test

Stage 5: Weighting each indicator

Stage 6: Person Correlation Test

Stage 7: Multiple Regression (Multivariate Analysis) 


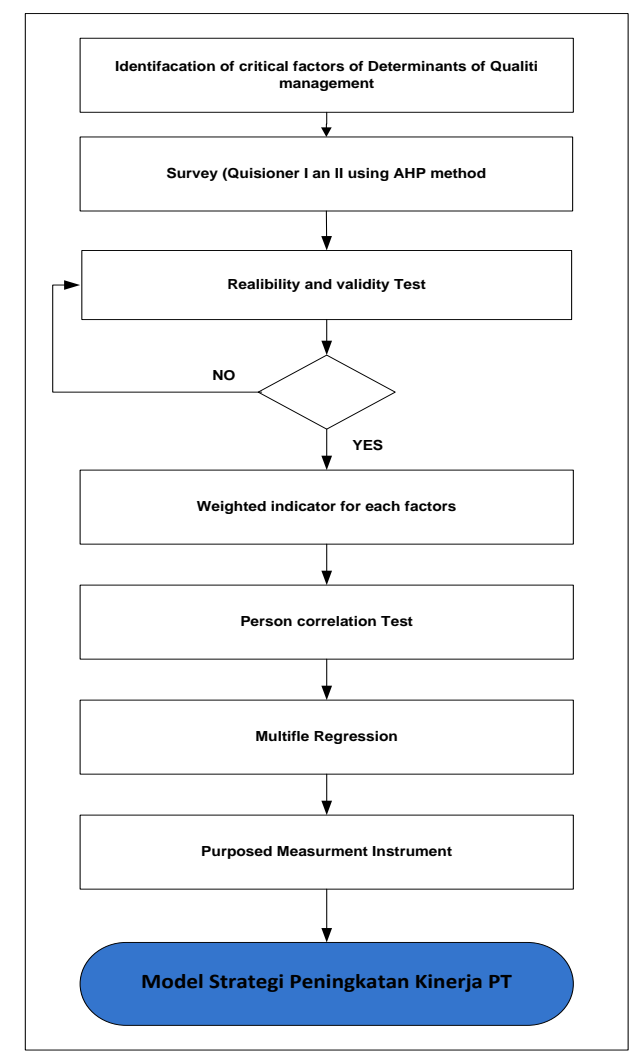

Fig 2. Chart of Research Flow

\section{AHP (Analytical Hierarchy Process) Method}

1. System design

Multiple attribute decision making system with AHP method at this stage the researcher takes the existing criteria to be used as an indicator in determining the factors that determine University Performance. These criteria will be made of 5 rating scales whose values are: $5=$ Strongly Agree, $4=$ Agree, $3=$ Disagree, $2=$ Disagree, $1=$ Strongly Disagree

2. Criteria needed

The variables used by researchers in this study were obtained from several previous studies. The variable used by the researcher is

$\mathrm{C} 1$ = Organizational Learning

$\mathrm{C} 2=$ External Environment

$\mathrm{C} 3$ = Reputation

$\mathrm{C} 4$ = Competence

C5 $=$ Professionalism

3. Analysis of Output Requirements

The expected output of this study is to obtain the weight of the value of the existing variables or variables so that the results of the determinants of strategies for increasing the University in Lampung Province are obtained. To get these variables made in a graph so that more clearly in the picture.

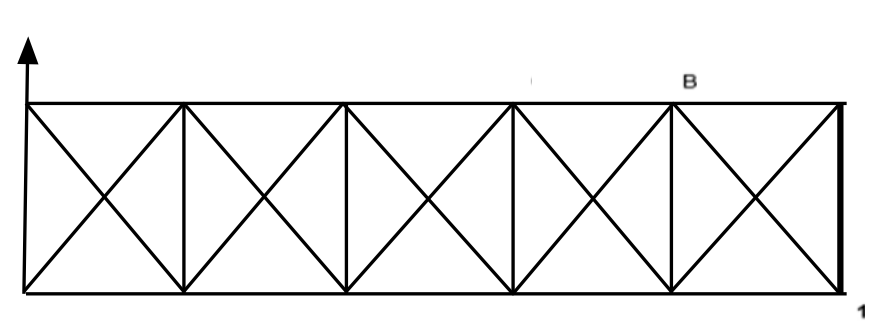

Information:

$>\mathrm{TB}=$ Not Good;

$>\mathrm{KB}=$ Poor;

$>\mathrm{CB}=$ Good enough;

$>\mathrm{B}=$ Good;

$>\mathrm{SB}=$ Very Good;

Fig. 3 Determining matrix of Higher Education Factors 


\section{Data Processing with AHP Method}

At this stage data processing is carried out in 2 stages, namely:

1. Combining respondents' assessment of the relative importance of each criterion and sub-criteria. Group assessment in AHP can be combined into one assessment, namely through the geometric average of the respondents' assessment. This assessment is an input for processing data using Expert Choice 2000.

2. Calculating the weight which is a priority for each criterion and sub criteria and the inconsistency ratio using Expert Choice 2000

\section{MDA (Multivariate Data Analysis) Method \\ Research Variables}

The following are the research variables for each indicator or factor based on table. 3 which will be used in the MDA analysis:

\begin{tabular}{|c|c|}
\hline Variables/Indicators & Sub Indicators \\
\hline Data Processing with AHP Metho & \\
\hline 1. Organizational Learning & $\begin{array}{l}\text { X1.1 Thinking System } \\
\text { X1.2 Mentality } \\
\text { X1.3 Personal Skills } \\
\text { X1.4 Team Cooperation } \\
\text { X1.5 Expertise sharing shared vision } \\
\text { X16 Dialog } \\
\text { (Marquardt, 1996, Hidayat, 2008) }\end{array}$ \\
\hline 2. External Environment & $\begin{array}{l}\text { X2.1 Government Regulation } \\
\text { X2.2 Market Dynamics } \\
\text { X2.3 Adaptation } \\
\text { (Masood, et al., 2000, Hidayat, 2008) }\end{array}$ \\
\hline 3. Reputation & $\begin{array}{l}\text { X3.1 Innovation } \\
\text { X3.2 Governance } \\
\text { X3.3 Social Responsibility } \\
\text { (Fortune, 1983, Hidayat 2008) }\end{array}$ \\
\hline 4. Competency & $\begin{array}{l}\text { X4.1 Quality of competence } \\
\text { X4.2 Scarcity of Competence } \\
\text { X4.3 Level. Competitor Difficulty Imitates } \\
\text { X4.4 Level. Lecturer Expertise } \\
\text { (Barney, 1991; Oliver 1997, Hidayat, 2008) }\end{array}$ \\
\hline 5. Professionalism & $\begin{array}{l}\text { X5.1 Scientific Mastery } \\
\text { X5.2 Academic Level } \\
\text { X5.3 Research Ability } \\
\text { X5.4 Community Service } \\
\text { (Suhat, 2007) } \\
\end{array}$ \\
\hline 6. $\quad$ Kinerja & $\begin{array}{l}\text { X6.1 Teaching Quality } \\
\text { X6.2 Number of Research } \\
\text { X6.3 Research Publications } \\
\text { X6.4 Development of Number of Students } \\
\text { (Dill, 1996; Thes 2007; Arwu, 2007, Hidayat, 2008) }\end{array}$ \\
\hline
\end{tabular}

\section{Analysis Method}

Analysis is done using the MDA method by using multiple regression model (multiple regression) to relate the influence of the independent variable (independent) to the dependent variable (dependent variable). Previously conducted Validity and Reliability Tests. Validity test is conducted to find out whether the measuring instrument actually measures what needs to be measured, namely by looking at the correlation between the value of each item question / statement with the total value of the validity test using techniques from the Spearman correlation or product moment coefficient. The criteria used for validity is if p 50.05 then it is declared valid. While for reliability stated reliable if $\alpha \geq 0.60$. Reliability testing is done by using Alpha Cronbach consistency to see how far a measuring instrument can be trusted or can be relied upon to be used as a data collection tool. 
The structural equation model based on the analysis of the variables above is the Regression Model. The results of the calculation of Ordinary Least Square (OLS) analysis are analyzed through the regression equation model as follows:

$$
\mathrm{Y} 1=\alpha+\beta 1 \mathrm{X} 1+\beta 2 \mathrm{X} 2+\beta 3 \mathrm{X} 3+\beta 4 \mathrm{X} 4+\beta 5 \mathrm{X} 5+\beta 6 \mathrm{X} 6+\mathrm{e}
$$

Information:

$\mathrm{Y} 1=$ Performance of PT

$\beta=$ constant

$\mathrm{X} 1$ = Organizational Learning

$\mathrm{X} 2=$ External Environment

$\mathrm{X} 3=$ Reputation

$\mathrm{X} 4$ = Competence

$\mathrm{X} 5=$ Professionalism

$\mathrm{X} 6=$ Performance

$\mathrm{e}=$ Error

\section{RESULTS}

\section{Determination of Respondents}

\section{Respondent}

The data in this study were obtained from several private tertiary institutions in Lampung Province which represented in several districts / cities of Lampung Province. The research sample is respondents who have filled out questionnaires. Respondents of this study focused on PTS leaders (chancellor or assistant chancellor I, II, or III; director or deputy director I, II, or III; chairman or vice chairman I, II, or III), ie one PTS will be represented by one respondent. This study will describe the perceptions of PTS leaders regarding organizational learning, the influence of the external environment, reputation, professionalism, competency strategy, and performance of the PTS. Selected PTS leaders as respondents, because they are considered the most aware of the conditions in the PTS in accordance with the variables of this study and have strategic capabilities in assessing the performance of PT.

Determination of the sample is done by justifying the researcher to determine the sample of respondents selected. The amount of sampling taken is determined by 10 people. The sample taken is respondents who are in the management level at the Higher Education (Chancellor/Chairperson, Deputy Chancellor / Deputy Chairperson or Dean)

Determination of samples is done by non probability sampling with random sampling techniques using a stratified random sampling approach. The amount of sampling taken is determined by 10 people. The sample taken is respondents who are in the management level at the Higher Education (Chancellor/Chairperson, Deputy Chancellor/ Deputy Chairperson or Dean)

\section{Research Location}

The location of this study is in several Private Universities in Lampung.

\section{Data Collection}

The data collection method used in this study was to use a questionnaire personally. Personal questionnaires are used to obtain data about the dimensions of the constructs that are being developed in this study. The Phase I questionnaire used in this study contains two main parts, namely:

a. The first part is about the social profile of the respondent, containing the respondent's data relating to the identity of the respondent and social conditions such as: age, gender, academic position, recent education, and tenure.

b. Whereas the second part contains questions related to the variables to be studied. The scale used as a variable measurement in the answer or questionnaire contents of the respondents is to use a scale like likert, which contains five levels of answers from 1 strongly disagree until 5 strongly agree.

\section{Research Object}

The following are the names of Private Universities in Lampung Province which were the objects of this study: 
Table 4 Private Universities which are the Research Samples

\begin{tabular}{cl}
\hline No & \multicolumn{1}{c}{ College } \\
\hline 1 & Universitas Bandar Lampung \\
2 & Institut Informatika dan Bisnis Darmajaya \\
3 & Universitas Teknorat Lampung \\
4 & Universitas Muhammadiyah Metro \\
5 & STMIK Pringsewu Lampung \\
6 & STIE Kalianda Lampung \\
7 & Universitas Sang Bumi Ruwa Jurai Lampung \\
8 & STIE Lampung Timur \\
9 & STMIK Kota Agung \\
10 & STIT Pringsewu Lampung \\
\hline
\end{tabular}

\section{Data Analysis}

\section{Data Collection}

The data collection method used in this study was to use a questionnaire personally. Personal questionnaires are used to obtain data about the dimensions of the constructs that are being developed in this study. The Phase I questionnaire used in this study contains two main parts, namely:

a. The first part is about the social profile of the respondent, containing the respondent's data relating to the identity of the respondent and social conditions such as: age, gender, academic position, recent education, and tenure.

b. Whereas the second part contains questions related to the variables to be studied. The scale used as a variable measurement in the answer or questionnaire contents of the respondents is to use a like likert scale, which contains five levels of answers from 1 strongly disagree until 5 strongly agrees.

\section{Phase 1 Questionnaire:}

a. At this stage researcher will weight the criteria that will be used to measure the performance of universities

b. From the weighting results, keriteria is ranked and arranged from the highest to the lowest

c. Then it is analyzed from the ranking results based on the level of importance of the criteria used

d. From the analysis, application software is designed to measure the performance of private universities in the pringsewu district.

\section{Data processing Phase 1 Questionnaire}

At this stage data processing is carried out by summing the scores given by each respondent on criteria and sub criteria according to the Likert scale principle. The following is the total score for each criterion and subcriteria.

Table 5 Scores of Criteria Total and Sub Criteria According to Respondents
\begin{tabular}{|l|l|l|}
\hline No & $\begin{array}{l}\text { Criteria and Sub Criteria for Private Higher } \\
\text { Education Performance Improvement Strategies } \\
\text { in Lampung }\end{array}$ & Score \\
\hline $\mathbf{1}$ & Organizational Learning & 44 \\
\hline $\mathbf{1 . 1}$ & Thinking System & 42 \\
\hline $\mathbf{1 . 2}$ & Mentality & 37 \\
\hline $\mathbf{1 . 3}$ & Personal expertise & 45 \\
\hline $\mathbf{1 . 4}$ & Teamwork & 44 \\
\hline $\mathbf{1 . 5}$ & Expertise shares shared vision & 37 \\
\hline $\mathbf{1 . 6}$ & Dialog & 40 \\
\hline $\mathbf{2}$ & External Environment & 42 \\
\hline $\mathbf{2 . 1}$ & Government regulations & 41 \\
\hline $\mathbf{2 . 2}$ & Market Dynamics & 40 \\
\hline $\mathbf{2 . 3}$ & Adaptation & 40 \\
\hline $\mathbf{3}$ & Reputation & $\mathbf{4 1}$ \\
\hline $\mathbf{3 . 1}$ & Innovation & 42 \\
\hline $\mathbf{3 . 2}$ & Governance & 44 \\
\hline $\mathbf{3 . 3}$ & Governance & 39 \\
\hline $\mathbf{4}$ & Competence & $\mathbf{4 0}$ \\
\hline
\end{tabular}




\begin{tabular}{|l|l|l|}
\hline $\mathbf{4 . 1}$ & Quality of Competence & 39 \\
\hline $\mathbf{4 . 2}$ & Scarcity of Competence & 39 \\
\hline $\mathbf{4 . 3}$ & Level of Competitor Difficulty Imitates & 35 \\
\hline $\mathbf{4 . 4}$ & Expertise Level & 44 \\
\hline $\mathbf{5}$ & Professionalism & 41 \\
\hline $\mathbf{5 . 1}$ & Scientific Mastery & 41 \\
\hline $\mathbf{5 . 2}$ & Academic Level & 44 \\
\hline $\mathbf{5 . 3}$ & Research Ability & 42 \\
\hline $\mathbf{5 . 4}$ & CSR & 40 \\
\hline $\mathbf{6}$ & Performance & $\mathbf{4 0}$ \\
\hline $\mathbf{6 . 1}$ & Teaching Quality & 44 \\
\hline $\mathbf{6 . 2}$ & Number of Research & 40 \\
\hline $\mathbf{6 . 3}$ & Research Publications & 39 \\
\hline $\mathbf{6 . 4}$ & Development of Number of Students & 35 \\
\hline
\end{tabular}

The researcher sets the criteria and selected sub criteria according to the respondent must have a minimum total score of $75 \%$ of the maximum total of $75 \%$ x 50 (10 respondent $\mathrm{x}$ score 5$)=37.5$ or $\approx 38$. This score is a logical score, because this value can represent agreement from 10 respondents. For example, if 10 respondents give a score of 4 (agree) and only 1 respondent gives a score of 3 (disagree) to a criterion or sub-criteria criteria, the total score is 39 so that the criteria / sub-criteria can be considered agreed and represented as criteria and sub criteria for improving PTS performance strategy. From this calculation, the selected criteria and sub criteria according to the respondents are as follows:

Table 6 Criteria and Sub Criteria Selected According to Respondents

\begin{tabular}{|l|l|l|}
\hline No & $\begin{array}{l}\text { Criteria and Sub Criteria for Private Higher Skor } \\
\text { Education Performance Improvement Strategies } \\
\text { in Lampung }\end{array}$ & \\
\hline $\mathbf{1}$ & Organizational Learning & 44 \\
\hline $\mathbf{1 . 1}$ & Thinking System & 42 \\
\hline $\mathbf{1 . 2}$ & Mentality & 45 \\
\hline $\mathbf{1 . 3}$ & Personal expertise & 44 \\
\hline $\mathbf{1 . 4}$ & Teamwork & 40 \\
\hline $\mathbf{2}$ & Expertise shares shared vision & 42 \\
\hline $\mathbf{2 . 1}$ & Dialog & 41 \\
\hline $\mathbf{2 . 2}$ & External Environment & 40 \\
\hline $\mathbf{2 . 3}$ & Government regulations & 40 \\
\hline $\mathbf{3}$ & Market Dynamics & $\mathbf{4 1}$ \\
\hline $\mathbf{3 . 1}$ & Adaptation & 42 \\
\hline $\mathbf{3 . 2}$ & Reputation & 44 \\
\hline $\mathbf{3 . 3}$ & Innovation & 39 \\
\hline $\mathbf{4}$ & Governance & $\mathbf{4 0}$ \\
\hline $\mathbf{4 . 1}$ & Governance & 39 \\
\hline $\mathbf{4 . 2}$ & Competence & 39 \\
\hline $\mathbf{4 . 3}$ & Quality of Competence & 44 \\
\hline $\mathbf{5}$ & Scarcity of Competence & 41 \\
\hline $\mathbf{5 . 1}$ & Level of Competitor Difficulty Imitates & 41 \\
\hline $\mathbf{5 . 2}$ & Expertise Level & 44 \\
\hline $\mathbf{5 . 3}$ & Professionalism & 42 \\
\hline $\mathbf{5 . 4}$ & Scientific Mastery & 40 \\
\hline $\mathbf{6}$ & Academic Level & $\mathbf{4 0}$ \\
\hline $\mathbf{6 . 1}$ & Research Ability & 44 \\
\hline $\mathbf{6 . 2}$ & CSR & 40 \\
\hline $\mathbf{6 . 3}$ & Performance & 39 \\
\hline
\end{tabular}

The results of this study indicate that the criteria and sub-criteria that are not selected or according to respondents have insufficient total scores 38 , namely: 

a. Mentality (Organizational Learning)
b. Expertise sharing shared vision (organizational learning)
c. Level of Competitor Imitation Difficulty (Competence)
d. Development of Student Numbers (Performance)

\section{Phase 2 Questionnaire:}

a. At this stage researcher will weight the criteria that will be used to measure the performance of universities

b. From the weighting results, keriteria is ranked and arranged from the highest to the lowest

c. Then it is analyzed from the ranking results based on the level of importance of the criteria used

d. From the analysis, application software is designed to measure the performance of private universities in the pringsewu district.

e. At this stage researcher will weight the criteria that will be used to measure the performance of universities

f. From the weighting results, keriteria is ranked and arranged from the highest to the lowest

g. Then it is analyzed from the ranking results based on the level of importance of the criteria used

h. From the analysis, application software is designed to measure the performance of private universities in the pringsewu district

\section{Description of Criteria for Questionnaire Results}

Based on the criteria selected by the respondent and the results of the calculation, the determination of criteria and sub criteria was obtained after distributing the Phase I questionnaire. The selected criteria and sub criteria were answered by the respondent so that the criteria will be used as a reference for improving the performance of PT. Likewise for the Phase II Questionnaire, respondents will determine the criteria and the most important subcriteria or will weight the criteria that will be used to measure the performance of the university. Therefore weights for each criterion and sub-criteria are obtained. This weight will show criteria and priority criteria. To fill in the pairwise comparison matrix, numbers are used to represent the relative importance of an element to other elements. This comparison scale can be seen in table 5.4. This scale defines and explains the values from 1 to 9 that are used for assessment in comparing elements in each level of a hierarchy to a criterion at the level above in pairs. Experience shows that a 9 units scale makes sense and shows the level at which we can distinguish the intensity of the relationship between elements.

\section{Results of Data Analysis Questionnaires Determine Priority of Criteria and Sub Criteria for} Measurement of Higher Education Performance

a. Main Criteria

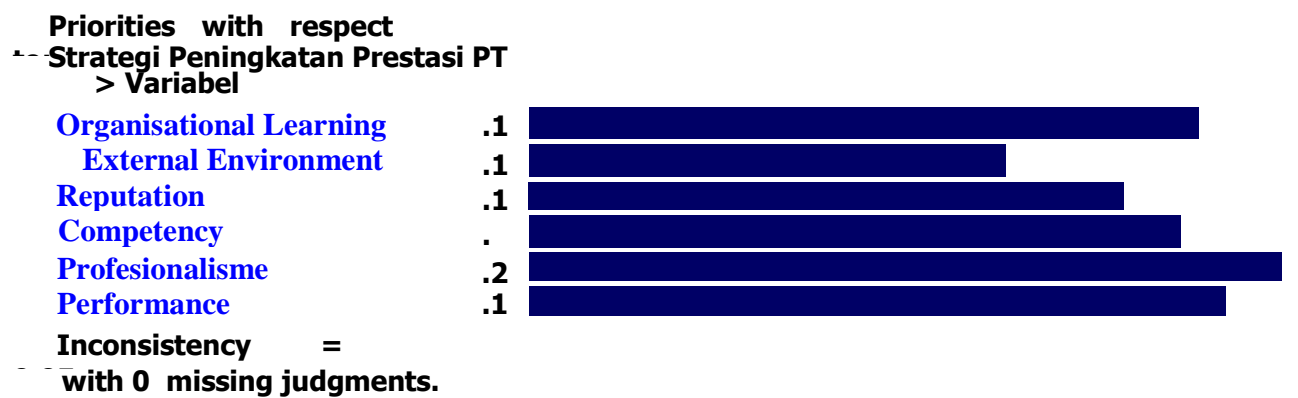

Based on the results of the criteria and sub criteria priority test using the AHP method, the main priority in measuring the performance of college is the highest weighting criteria of Professionalism (0.200). The second priority is the Performance criteria with weights $(0.185)$ and the third priority is organizational learning with weights $(0.180)$

b. Sub Criteria (sub indicator)

Sub Organizational Learning Criteria 
Priorities with respect to:

Strategi Peningkatan Prestasi PT

$>$ sub criteria pembelajaran organisasi

System Berpikir

Mentelitas

Keahlian Propesional

Kerjasama Team

Keahlian Mebagi Visi Bersama

Dialog

.160

.170

.180

.185

.150

.155

Inconsistency $=0.02$

with 0 missing judgments.

The highest priority for the Organizational Learning sub-criteria is Team Collaboration, which is 0.185.

Next is the Proposal Expertise which has a weight of 0.180 .

c. Sub External Environment Criteria

Priorities with respect to:

Strategi Peningkatan Prestasi PT

> sub criteria Lingkungan External

Peraturan Pemerintah

Kedinamisan Pasar

.355

.310

Adaptasi

.335

Inconsistency $=0.01$

with 0 missing judgments.

The highest priority for the External Environment sub criteria is Team Collaboration, which is 0.185 . Next is the Proposal Expertise which has a weight of 0.180 .

d. Reputation criteria

Priorities with respect to:

Strategi Peningkatan Prestasi PT

$>$ sub criteria Reputasi

Inovasi

Tata Kelola

Tanggung Jawab Sosial

Inconsistency $=0.05$

with 0 missing judgments.

The highest priority for the Reputation sub criteria is Governance, which is 0.355 . Next is the innovation that has a weight of 0.325

e. Competency Sub Criteria

Priorities with respect to:

Strategi Peningkatan Prestasi PT $>$ sub criteria Kompetensi

Kualitas Kompetensi

Kelangkaan Kompetensi

.255

Tingkat kesulitanpesaing meniru

Tingkat kepakaran Dosen

.245

Inconsistency $=0.01$

.240

with 0 missing judgments.

The highest priority for the Competency sub criteria is the Lecturer Expertise Level, which is 0.260. Next is the Proposal Expertise which has a weight of 0.255 . 
f. Professional Sub Criteria

Priorities with respect to:

Strategi Peningkatan Prestasi PT

$>$ sub criteria Profesionalisme

Penguasaan Keilmuan

Jenjang Akademik

Kemampuan Penelitian

Pengabdian Masyarakat

Inconsistency $=0.02$

with 0 missing judgments.
.265

.230

.255

.250

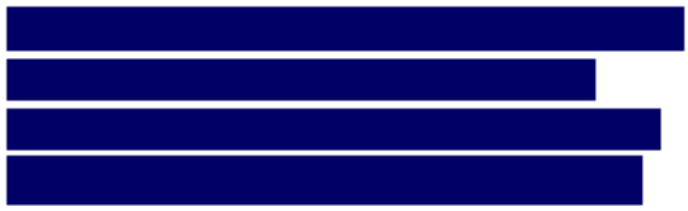

The highest priority for the Professional sub criteria is the Level of Scientific Mastery, which is 0.265. Next is the Research Ability which has a weight of 0.255 .

g. Performance Criteria Sub

Priorities with respect to:

Strategi Peningkatan Prestasi PT

$>$ sub criteria Kinerja

Kualitas Pengajaran

Jumlah Penelitian

Publikasi Peneliiian

.230

Perkembangan Jumlah Mahasiswa

.270

Inconsistency $=\mathbf{0 . 0 1}$

with 0 missing judgments.

The highest priority for the Performance sub-criteria is the Research Publication, which is 0.270 . Next is the Teaching Quality which has a weight of 0.260 .

7. Regression Analysis using MDA

a. Higher Education Performance Regression Test Results

b. The following are the results of several factors that influence the performance of Private Universities in Lampung Province. These factors have an influence on improving the performance of College.

Table 7 Higher Education Performance Regression Test Results

Coefficients $^{\mathrm{a}}$

\begin{tabular}{|c|c|c|c|c|c|}
\hline \multirow[b]{2}{*}{ Model } & \multicolumn{2}{|c|}{$\begin{array}{l}\text { Unstandardized } \\
\text { Coefficients }\end{array}$} & \multirow{2}{*}{$\begin{array}{c}\begin{array}{c}\text { Standardized } \\
\text { Coefficients }\end{array} \\
\text { Beta }\end{array}$} & \multirow[b]{2}{*}{$\mathrm{t}$} & \multirow[b]{2}{*}{ Sig. } \\
\hline & $\mathrm{B}$ & Std. Error & & & \\
\hline 1 (Constant) & 1.362 & .497 & & 2.739 & .010 \\
\hline PEM_ORG & .490 & .087 & .650 & 5.654 & .000 \\
\hline LING_EKS & .227 & .130 & .317 & 1.742 & .010 \\
\hline REPUTASI & .301 & .131 & .413 & 2.288 & .00 \\
\hline KOMPETENSI & .431 & .111 & .344 & 2.333 & .0 \\
\hline PROFESIONALISME & .411 & .165 & .550 & 3.482 & .000 \\
\hline KINERJA & .331 & .177 & .430 & 2.510 & .000 \\
\hline
\end{tabular}

Based on the table above the regression results of the University's performance supporting factors that can improve the performance of PTs, especially the private sector, show that the significance value (p-value) is Organizational Learning (0.00), External Environment (0.10), Reputation (0.08), Competence (0.00), 
Professionalism (0.00), and Performance $(0.00)$ have significance $<0.05$. These results indicate that the overall factors tested have a significant effect on improving the performance of College.

The following are the results of a simultaneous test of the supporting factors for improving the performance of Private Universities:

Table 8 Simultaneous Test Results of Higher Education Performance

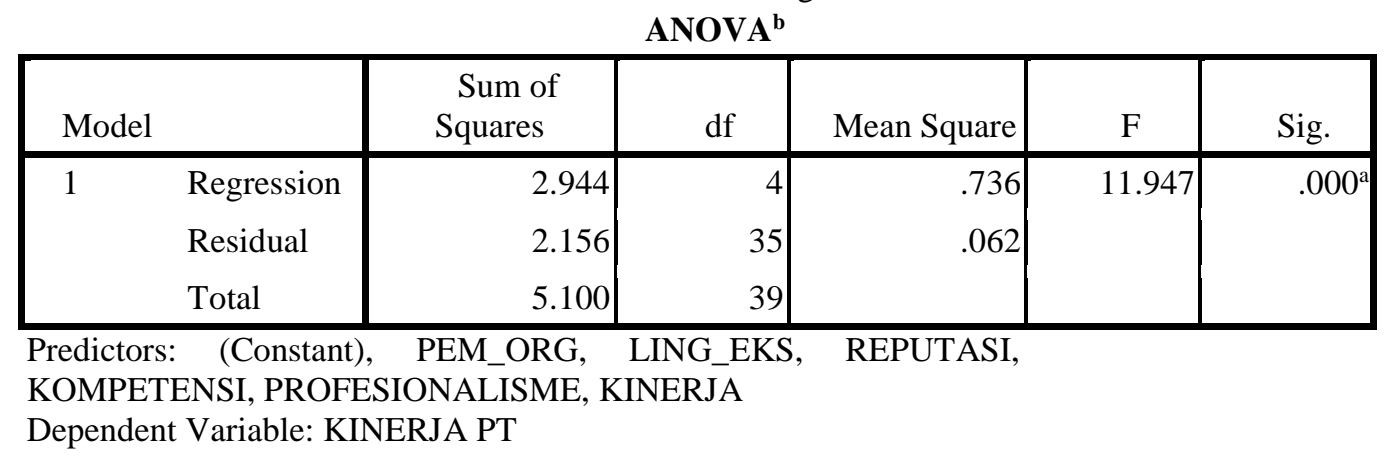

The table above shows the results of the simultaneous test of Higher Education Performance factors. Based on the significance test the effect is simultaneously obtained $F$ count of 11.947 with a significance probability of 0.000. This shows that Organizational Learning, External Environment, Reputation, Competence, Professionalism, and Performance influence the Performance of College.

\section{CONCLUSIONS}

This study aims to obtain the factors included in the criteria and determinants in the strategy of improving the performance of Private Universities in Lampung Province. This study also determines the weight and priority of criteria and the subcriteria for the assessment of PT performance determinants in Lampung Province using the AHP Method and also analyzing the relationship and influence of criteria and sub criteria on PT performance using the Multivariate Data Analysis (MDA) method. This study uses a sample of respondents who occupy the management level in Private Universities in Lampung province (Chancellor / Chairperson, Deputy Chancellor / Deputy Chairperson or Dean) that is using the justified method and obtained 10 respondents.

The results of this study are answers to questionnaires from the respondents using a Likert scale, which contains five levels of answers from 1 strongly disagree until 5 strongly agrees. Obtained criteria and sub-criteria for measuring the performance of private universities in Lampung province, namely: 6 criteria and 20 sub-criteria selected. The results of the study indicate that the priority criteria are Professionalism.

The results of the influence test show that Organizational Learning, External Environment, Reputation, Competence, Professionalism, and Performance influence the Performance of PT. These criteria and sub-criteria are used as references for PTS management as a strategy to improve PTS performance in Lampung Province

\section{REFERENCES}

[1] Abadi, S., Widyarto, S. (2018). The Designing Criteria and Sub-Criteria of University Balance Scorecard Using Analytical Hierarchy Process Method. International Journal of Engineering and Technology(UAE) DOI: 10.14419/ijet.v7i2.29.14260

[2] Abadi, S., Widyarto, S. (2016) The Model Of Determining Quality Of Management Private Higher Education Using Fahp (Fuzzy Analytic Hierarchy Process) Method. ICESIA, 2016

[3] Abadi, S., Teh, K.S.M., Nasir, B.M., Huda, M., Ivanova, N.L., Sari, T.I., Maseleno, A., Satria, F., Muslihudin, M. Application Model of K-Means Clustering Insights into Promotion Strategy of Vocational High School. International Journal of Engineering and Technology (UAE)

[4] Barney, J. B., (2002), Gaining And Sustaining Competitive Advantage, Second Edition. Prentice Hall

[5] David, F.R., 2002, Manajemen Strategis: Konsep, Edisi Bahasa Indonesia. Diterjemahkan oleh Alexander Sindoro. Jakarta: Prenhallindo.

[6] Feridani, Elena. (2005). Perancangan Metode Pembobotan Kriteria Pemilihan Pemasok Dengan Metode Analytic Hierarchy Process (AHP) dan Fuzzy AHP. (Studi Kasus Pemilihan Pemasok Jasa 
Pemeliharaan Fasilitas Off Shore di PT.X. Tesis Universitas Indonesia.

[7] Hall, Richard, (1992), The Strategic Analysis of Intangible Resources. Strategic Management Journal, 13, 135

[8] Hall, Richard, (1993), A Framework Linking Intangible Resources and Capabilities to Sustainable Competitive Advantage, Strategic Management Journal, 14, 607

[9] Hair, J. F., Anderson, R. E., Tatham, R. L. \& Black, W. C., (1998), Multivariate Data Analysis, 5th Edition, Prentice Hall, Upper Saddle River, USA

[10]Handoko TH. (1985). Manajemen Personalia dan Sumber Daya Manusia. Yogyakarta (ID):

[11]Hidayat D.S. (2008) Strategi Membangun Kompetensi Organisasi Dalam Rangka Meningkatkan Kinerja Perguruan Tinggi Swasta (PTS) Di Jawa Tengah. Tesis UNDIP

[12] Khandekar, A. \& A. Sharma, (2006). Organizational Learning and Performmance: Understanding Indian Scenario in Present Global Context, Education amd Training, Vol.48 No.8/9, 682.

[13] Kotler, Philip, 2003, Marketing Management, Elevent Editions, Prentice Hall International Inc, New Jersey.

[14] Kusmanto, H. (2017) Analisis Indeks Kinerja Dosen (Ikd) Dengan Menggunakan Structural Equation Model (SEM). Journal for Islamic Social Sciences. Holistik 1(2): 146-157

[15]Kusumadewi, Sri. (2004). Fuzzy Quantification Theori untuk Analisis Hubungan antara Penilaian Kinerja Dosen oleh Mahasiswa, Kehadiran Dosen, dan Nilai Kelulusan. Media Informatika. Jurusan Teknik Informatika, Fakultas Teknologi Industri Universitas Islam Indonesia.

[16]Liberty. Hasibuan SP. (1997). Manajemen Sumber Daya Manusia. Jakarta (ID): PT Toko Gunung Agung

[17] Mathis L. (2006). Human Resources Management. Jakarta (ID): Salemba Empat.

[18]Marquardt, M.J., (1996). Building the Learning Organization. New York: McGrawHill Companies, Inc.

[19] Saaty, Thomas-L" (1993). Analitik Pengambilan Keputuan Bagi para pemimpin, proses Hirarki untuk Pengambilan Keputusan dalam situasi Kompleks, seri Manajemen No. 134. Jakarta : PT. pustaka Binaman pressindo.

[20] Saaty, Thomas L', (1990). Decision Making for Leaders - The Analyical Hierarchy process Decisions for in a Company World',RWS publication.

[21] Suta, I Putu Gede Ary, (2005)., Kinerja Pasar Perusahaan Publik di Indonesia: Suatu Analisis reputasi Perusahaan, Yayasan Sad Satria Bhakti, Jakarta.

[22] Wang, Y. and H. Lo, (2003). Customer-focused Performance and the Dynamic Model for Competences Building and Leveraging: A Resource-based View, Journal of Management Development, (22), No.6, pp.483 